\title{
Glauconitic Siltstone as a Source of Potassium, Silicon and Manganese for Flooded Rice
}

\author{
Rafael Gómez Arrieta ${ }^{1}$, Camila de Andrade Carvalho Gualberto ${ }^{1}$, Thiago Siqueira Prudente ${ }^{1}$, \\ Gustavo Alves Santos ${ }^{1}$, Luiz Henrique Silveira ${ }^{1}$, Bruno Nicchio ${ }^{1} \&$ Hamilton Seron Pereira ${ }^{1}$ \\ ${ }^{1}$ Institute of Agricultural Sciences, Federal University of Uberlândia, Uberlândia, Brazil \\ Correspondence: Camila de Andrade Carvalho Gualberto, Institute of Agricultural Sciences, Federal University of \\ Uberlândia, Amazonas Avenue, building 4C, room 123, P.O. Box 38400-902, Uberlândia, MG, Brazil. Tel: \\ 55-34-99894-3552. E-mail: camila_carvalho03@hotmail.com
}

Received: May 25, 2020

doi:10.5539/jas.v12n9p96
Accepted: July 6, $2020 \quad$ Online Published: August 15, 2020

URL: https://doi.org/10.5539/jas.v12n9p96

\begin{abstract}
The objective of this study was to evaluate the efficiency of glauconitic siltstone as a multi-nutrient source for flooded rice. Two experiments were carried out under greenhouse conditions, one using a Ferralsol and the another an Arenosol. Glauconitic siltstone was applied in different doses $\left(0,5,20,40\right.$, and $\left.80 \mathrm{mg} \mathrm{dm}^{-3} \mathrm{~K}_{2} \mathrm{O}\right)$ and potassium chloride, wollastonite, and manganese sulfate were respectively used as standard sources, at doses of $80 \mathrm{mg} \mathrm{dm}^{-3} \mathrm{~K}_{2} \mathrm{O}, 270 \mathrm{mg} \mathrm{dm}^{-3} \mathrm{Si}$, and $2 \mathrm{mg} \mathrm{dm}^{-3} \mathrm{Mn}$. The sources were incubated for 90 days on the two soil types and, after the incubation period, rice plants were sown, and two consecutive rice growths were performed. The application of glauconitic siltstone in tropical soils promotes increases in the plant and grain dry matter of rice plants, as well as $\mathrm{K}, \mathrm{Si}$ and $\mathrm{Mn}$ contents in soil samples and accumulated in plants. Greater effects following the application of glauconitic siltstone are obtained after the second rice growth due to its gradual release.
\end{abstract}

Keywords: Oryza Sativa, beneficial elements, multi-nutrient source, rice-yields, sustainable agriculture

\section{Introduction}

Potassium chloride $(\mathrm{KCl})$ is the most used source of potassium $(\mathrm{K})$ fertilizer in the world (Ernani et al., 2007). However, crops fertilized with high $\mathrm{KCl}$ doses can present significantt chlorine $(\mathrm{Cl})$ accumulation in leaves, which may inhibit some metabolic processes (Geilfus, 2018), as well promoting soil salinity and, as a consequence, water stress to plants (Watanabe et al., 2017).

Moreover, intensive application of $\mathrm{KCl}$ may also result in losses of $\mathrm{K}$ by leaching, since the $\mathrm{K}$ ion has a greater hydration radius than most other cations, resulting in a low retention cation-exchange capacity of soil (Dolcater et al., 1968). Potassium leaching is often a problem, especially in tropical areas with soil fertility constraints.

The total amount of $\mathrm{K}$ in Brazilian soils ranges from 0.5 to $25 \mathrm{~g} \mathrm{dm}^{-3}$ (Ribeiro et al., 2010). Despite being the most absorbed element for the majority of crops, the content of soil available $\mathrm{K}$ to plants is low.

Recent investigations suggest that the addition of glauconite-rich rocks may increase the K content in soils (Zörb et al., 2014). In Russia, glauconitic sandstone is a K-rich rock used in K fertilizer production. In addition, there are reports of the use of glauconitic sandstone as $\mathrm{K}$ fertilizer in India and in some African countries, resulting in higher soil K contents and superior yields (Karimi et al., 2012).

In Brazil, especially in Minas Gerais state, the glauconitic siltstone (GS) could allow the country to become self-sufficient in K-fertilizing for several decades (Nader \& Ackroyd, 2017). GS is a dark-green, fine grained siltstone, usually laminated, composed of glauconite (40-80\%), quartz (10-20\%), K-feldspar (10-15\%), muscovite $(5 \%)$, biotite $(2 \%)$, and traces of titanium oxide, manganese oxide, goethite $(<1 \%)$, barium and rare-earth elements phosphates (Moreira et al., 2016). The average $\mathrm{K}_{2} \mathrm{O}$ total is $10 \%$ (Nader \& Ackroyd, 2017). GS provides $\mathrm{K}_{2} \mathrm{O}$ and no $\mathrm{Cl}$, allowing for use on organic agriculture. In addition, GS has silicon ( $\mathrm{Si}$ ) and manganese (Mn), with the potential to be used not only as a $\mathrm{K}$ fertilizer, but also as a multi-nutrient fertilizer (Violatti et al., 2019).

In this context, GS could reduce the demand for $\mathrm{KCl}$, which may deplete soils and their microbiota when inappropriately managed (Karimi et al., 2012). The objective of this study was to evaluate the efficiency of GS as a multi-nutrient source for flooded rice. This crop was chosen since yield responses in rice to soil $\mathrm{K}, \mathrm{Si}$ and 
Mn amendments have frequently been recorded on weathered tropical or sub-tropical soils on which they are mainly grown. Owing to its capability to supply K, Si and Mn to plants, we expect to promote an innovative and sustainable use of GS powder in agricultural areas.

\section{Materials and Methods}

Two experiments were carried out under greenhouse conditions from $02 / 28 / 2016$ to $10 / 29 / 2016$, one using a clayey soil and the another, a sandy soil. The samples of the two different soil types were collected at $0-20 \mathrm{~cm}$ soil layer in Uberlândia, Minas Gerais, Brazil, which were classified as Ferralsol (Oxisol in Soil Taxonomy; Latossolo Vermelho Distrófico according to Santos et al., 2013) (69\% of clay, $\mathrm{pH}\left(\mathrm{CaCl}_{2}\right) 4.4,6.6 \mathrm{mg} \mathrm{dm}^{-3} \mathrm{Si}, 20$ $\mathrm{mg} \mathrm{dm}{ }^{-3} \mathrm{~K}, 0.3 \mathrm{cmolc} \mathrm{dm}^{-3} \mathrm{Ca}$, and $0.02 \mathrm{mg} \mathrm{dm}^{-3} \mathrm{Mn}$ ) and Arenosol (Entisol in Soil Taxonomy; Typical Neossolo Quartzarênico Órtico according Santos et al., 2013) (9\% clay, $\mathrm{pH}\left(\mathrm{CaCl}_{2}\right) 4.4,3.3 \mathrm{mg} \mathrm{dm}{ }^{-3} \mathrm{Si}, 20 \mathrm{mg}$ $\mathrm{dm}^{-3} \mathrm{~K}, 0.2 \mathrm{cmolc} \mathrm{dm}^{-3} \mathrm{Ca}$, and $0.12 \mathrm{mg} \mathrm{dm}^{-3} \mathrm{Mn}$ ) (FAO, 2015).

GS used in the experiment was characterized according to macro and micronutrient contents, determined on a flame photometer according to the method described by MAPA (2017), $10 \mathrm{~g} \mathrm{~kg}^{-1}$ total K $2 \mathrm{O}, 270 \mathrm{~g} \mathrm{~kg}^{-1}$ total Si, and $0.5 \mathrm{~g} \mathrm{~kg}^{-1}$ total $\mathrm{Mn}$. Wollastonite $\left(230 \mathrm{~g} \mathrm{~kg}^{-1} \mathrm{Si}, 303 \mathrm{~g} \mathrm{~kg}^{-1} \mathrm{Ca}\right.$, and $\left.110 \mathrm{~g} \mathrm{~kg}^{-1} \mathrm{Mg}\right), \mathrm{KCl}\left(600 \mathrm{~g} \mathrm{~kg}^{-1} \mathrm{~K}_{2} \mathrm{O}\right)$ and manganese sulfate $\left(\mathrm{MnSO}_{4}\right)\left(310 \mathrm{~g} \mathrm{~kg}^{-1} \mathrm{Mn}\right)$ were used as standard sources for comparison purposes. The chemical characteristics of nutrient sources used in this study were determined according to methodology described by Teixeira et al. (2017) and Korndörfer et al. (2004) (Si analysis). The treatments were applied to soils as a $<2 \mathrm{~mm}$ powder.

Both experiments were arranged in randomized blocks, design with four replications. Four GS rates were used according to the total $\mathrm{K}_{2} \mathrm{O}$ content $\left(10 \mathrm{~g} \mathrm{~kg}^{-1} \mathrm{~K}_{2} \mathrm{O}\right.$-resulting in the following doses: $0,5,20,40$, and $80 \mathrm{mg} \mathrm{dm}^{-3}$ $\left.\mathrm{K}_{2} \mathrm{O}\right)$, which resulted in four $\mathrm{Si}\left(270,1080,2160\right.$, and $\left.4320 \mathrm{mg} \mathrm{dm}^{-3} \mathrm{Si}\right)$ and $\mathrm{Mn}$ doses $\left(0.5,2,4\right.$, and $8 \mathrm{mg} \mathrm{dm}^{-3}$ $\mathrm{Mn})$. Standard treatments were also used as checks: $\mathrm{KCl}\left(80 \mathrm{mg} \mathrm{dm}^{-3} \mathrm{~K}_{2} \mathrm{O}\right)$, wollastonite $+\mathrm{KCl}\left(270 \mathrm{mg} \mathrm{dm}^{-3} \mathrm{Si}\right.$ $\left.+80 \mathrm{mg} \mathrm{dm}^{-3} \mathrm{~K}_{2} \mathrm{O}\right)$, manganese sulfate $\left(\mathrm{MnSO}_{4}\right)+\mathrm{KCl}\left(2 \mathrm{mg} \mathrm{dm}^{-3} \mathrm{Mn}+80 \mathrm{mg} \mathrm{dm}^{-3} \mathrm{~K}_{2} \mathrm{O}\right)$, which resulted in 32 pots for each soil type.

Since wollastonite supplies $\mathrm{Ca}$ and $\mathrm{Mg}$ to plants, different rates of $\mathrm{CaCO}_{3}$ and $\mathrm{MgCO}_{3}$ were added to adjust the amounts of $\mathrm{Ca}$ and $\mathrm{Mg}$ in all treatments and increase soil base saturation to $70 \%$ and $90 \%$ in clayey and sandy soil, respectively.

The products were incubated for 90 days in $8 \mathrm{dm}^{-3}$ of the two different soil types. In order to maintain humidity, around $80 \%$ of the field capacity value for each soil, deionized water was added to pots. Soil moisture was rigorously controlled by daily weighing of the plastic containers, replacing the volume lost through evapotranspiration with deionized water.

After the incubation period, $200 \mathrm{mg} \mathrm{kg}^{-1} \mathrm{~N}$ and $400 \mathrm{mg} \mathrm{kg}^{-1} \mathrm{P}_{2} \mathrm{O}_{5}$ were added to samples through ammonium sulfate and triple superphosphate, respectively. The micronutrients were supplied via solution at the rates of 1.5; 5.0; 0.5 , and $0.05 \mathrm{mg} \mathrm{dm}{ }^{-3} \mathrm{Cu}, \mathrm{Zn}, \mathrm{B}$, and $\mathrm{Mo}$, through the sources $\mathrm{CuSO}_{4} \cdot 5 \mathrm{H}_{2} \mathrm{O} ; \mathrm{ZnSO}_{4} \cdot 7 \mathrm{H}_{2} \mathrm{O} ; \mathrm{H}_{3} \mathrm{BO}_{3}$ and $\left(\mathrm{NH}_{4}\right)_{6} \mathrm{Mo}_{7} \mathrm{O}_{24} \cdot 4 \mathrm{H}_{2} \mathrm{O}$, respectively. Then, BRS Atalanta irrigated cycle rice cultivar was sown, which presents smooth grains and leaves, high tillering capacity, and strong stalks (Embrapa, 2007). Fifteen seeds were sown per pot, at a depth of $2 \mathrm{~cm}$. After the emergence, thinning was carried out, maintaining 6 plants per pot. At this time, a $2 \mathrm{~cm}$ water irrigation level was also added, which was maintained until 15 days before harvesting.

Rice plants were harvested at 89 days after sowing (DAS), and at the same time, the soil samples were collected. Plants samples were dried in an oven and weighed to obtain the plant dry matter (DM) and grain DM values. Afterwards, the samples were ground and submitted to nitric-perchloric digestion. The $\mathrm{K}$ and $\mathrm{Mn}$ concentrations were analyzed by flame spectrophotometry and atomic absorption spectrophotometry (Teixeira et al., 2017), respectively, whereas Si concentrations were measured at $630 \mathrm{~nm}$ using an ultraviolet (UV) visible spectrophotometer (Korndörfer et al., 2004). The product of the plant DM and nutrient concentration in plant samples resulted in the values of $\mathrm{K}, \mathrm{Si}$, and $\mathrm{Mn}$ accumulated in rice plants.

Soil chemical analyses were performed according to Korndörfer et al. (2004) (soil available Si content) and Teixeira et al. (2017) (soil available K-Resin extraction and Mn contents).

Using the nutrient accumulated values, relative agronomic efficiency (RAE) of GS relative to $\mathrm{KCl}$ was calculated using the following equation as proposed by Fageria et al. (2010):

$$
\mathrm{RAE}(\%)=\frac{\mathrm{GSDM}-\text { control DM }}{\mathrm{KClDM}-\text { control DM }} \times 100
$$


where, GS DM is the plant DM with the application of GS $\left(80 \mathrm{mg} \mathrm{dm}^{-3} \mathrm{~K}_{2} \mathrm{O}\right)$, based on the total $\mathrm{K}_{2} \mathrm{O}$; $\mathrm{KCl} \mathrm{DM}$ is the plant DM, with the application of $\mathrm{KCl}\left(80 \mathrm{mg} \mathrm{dm}^{-3} \mathrm{~K}_{2} \mathrm{O}\right)$; the control DM is the plant DM in the control treatment, without $\mathrm{K}_{2} \mathrm{O}$ application $\left(0 \mathrm{mg} \mathrm{dm}^{-3} \mathrm{~K}_{2} \mathrm{O}\right)$.

After the first rice growth, a second rice growth was conducted to evaluate the residual effect of the sources applied. Thus, the same rice cultivar was sown in the same treatments previously cultivated, but, in this case, without the application of GS, $\mathrm{KCl}$, wollastonite, or manganese sulfate. The experiment followed the same management and analyses as the previous one.

Normality test was applied to verify if the data had a normal distribution. All results showed a normal distribution. Then, data was subjected to variance analysis, followed by regressions analysis at $5 \%$ probability. All analyses were performed using the software SigmaPlot 11.0 (Systat Software, 2008).

\section{Results and Discussion}

The effects of GS on plant and grain DM yields, after two consecutive rice growths, as compared to $\mathrm{KCl}$, ranged from 35 to $64 \mathrm{~g} \mathrm{pot}^{-1}$ and from 13 to $30 \mathrm{~g} \mathrm{pot}^{-1}$, after the first rice growth in clayey and sandy soil, respectively (Figure 1). As regards the DM of rice plants grown in sandy soil, it was found that the GS, at a dose of $60 \mathrm{~kg} \mathrm{ha}^{-1}$ $\mathrm{K}_{2} \mathrm{O}$, presented the highest values (Figure $1 \mathrm{~b}$ ), while linear increases of $3.7 \mathrm{~g} \mathrm{pot}^{-1}$ were observed for every 10.0 $\mathrm{mg} \mathrm{dm} \mathrm{K}_{2}^{-3} \mathrm{O}$ applied to the clayey soil (Figure 1a).

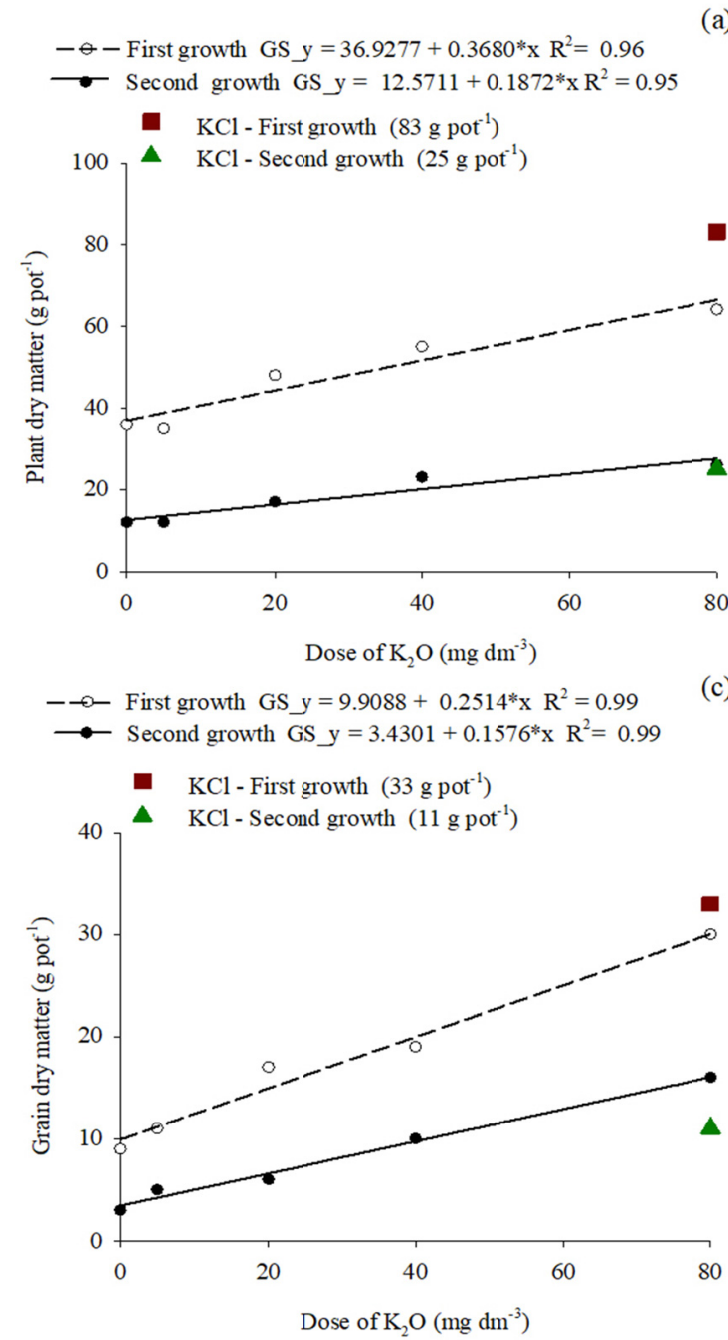

(a)

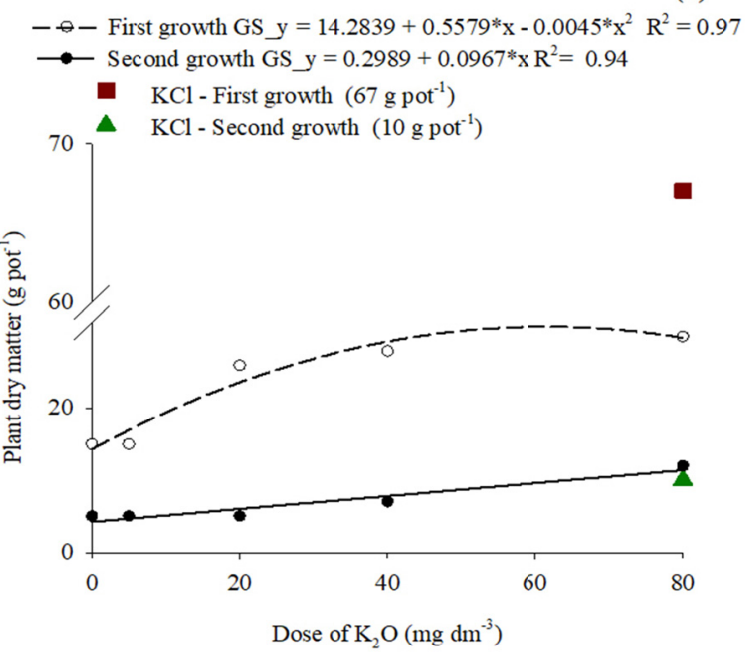

(c)

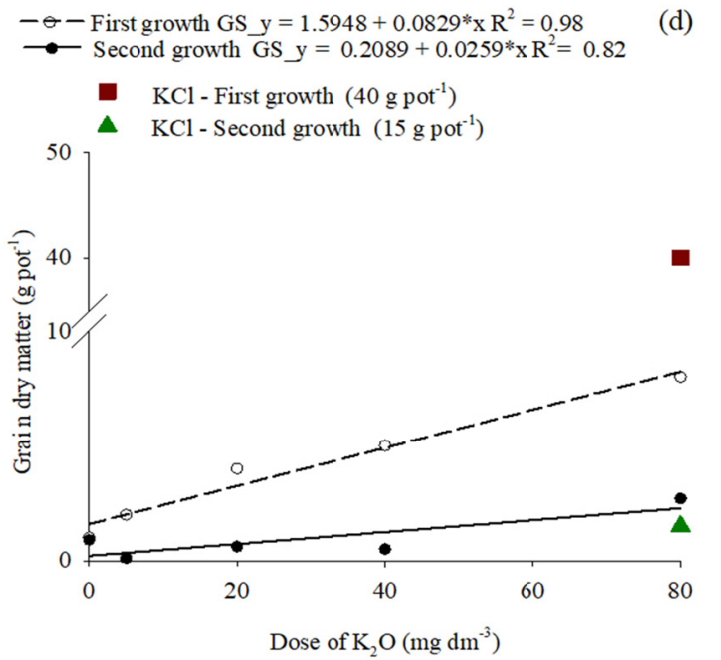

Figure 1. Plant dry matter of rice plants growth in clayey (a) and sandy (b) soils and grain dry matter of rice plants growth in clayey (c) and sandy (d) soils with increasing doses of $\mathrm{K}_{2} \mathrm{O}$ through glauconitic siltstone (GS) after two consecutive rice growths. Square and triangle symbols refer to the $\mathrm{KCl}$ treatment at dose of $80 \mathrm{mg} \mathrm{dm}^{-3}$ $\mathrm{K}_{2} \mathrm{O}$ after the first and second rice growth, respectively 
After the second growth, these values ranged from 12 to $26 \mathrm{~g} \mathrm{pot}^{-1}$ in clayey soil and from 5 to $12 \mathrm{~g} \mathrm{pot}^{-1}$ in sandy soil (Figure 1). Linear increases of plant DM after the second growth were observed following the increase of GS dose to the soil; for every $10 \mathrm{mg} \mathrm{dm}^{-3}$ applied to the clayey and sandy soil, there was an increase in plant DM of 1.9 and $1.0 \mathrm{~g} \mathrm{pot}^{-1}$, respectively (Figures $1 \mathrm{a}$ and $1 \mathrm{~b}$ ). In general, higher response to GS application was observed in clayey soil, since the soil type affects the availability of $\mathrm{K}$ to plants. Potassium leaching is frequently related to the soil texture, being the most easily leached cation, especially in sandy soils, due to its displacement to the solution and to its percolation (Mendes et al., 2016), making it less available to plants.

After the first rice growth, the application of GS resulted in an increase in plant and grain DM, compared to the check, without $\mathrm{K}_{2} \mathrm{O}$, yet the effects were not comparable with the $\mathrm{KCl}$ application (Figure 1). The greater yields provided by the standard source were due to the greater solubility, which is mostly water-soluble and readily available to plants (Prakash \& Verma, 2016). However, in the second rice growth, GS promoted higher plant and grain $\mathrm{DM}$ values than the $\mathrm{KCl}$ application.

In general, relative agronomic efficiency (RAE) values following GS application were smaller than $\mathrm{KCl}$ values (values minor than 100\%) after the first rice growth (Figure 2). In contrast, after the second rice growth, GS sources presented greater agronomic efficiency (values higher than $100 \%$ ), indicating a good prospect for gradual release use, as previously discussed.

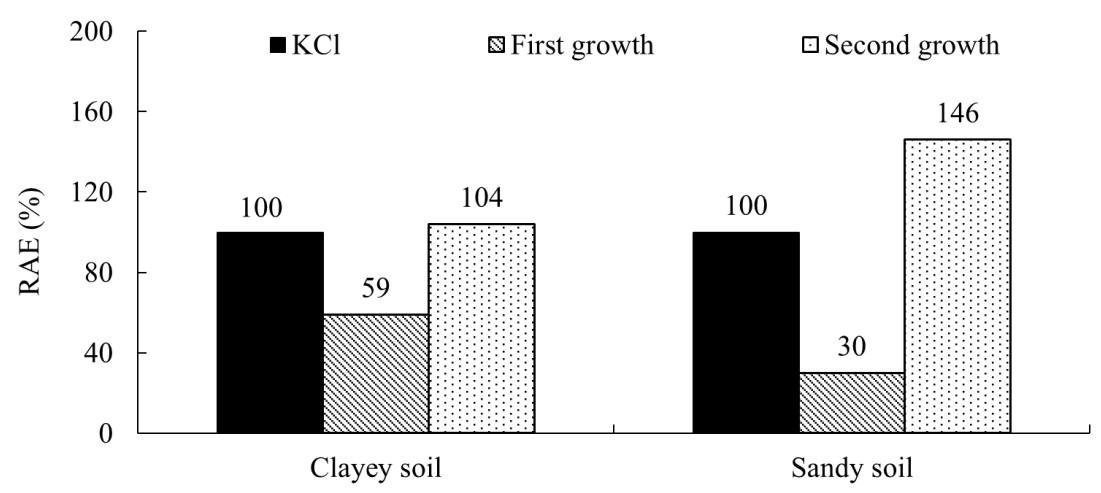

Figure 2. Relative Agronomic efficiency (RAE) (\%) of glauconitic siltstone in relation to $\mathrm{KCl}$ in clayey and sandy soils after two consecutive rice growths

The application of increased doses of GS improved the contents of $\mathrm{K}$ in soil and accumulated in rice plants (Figure 3). 


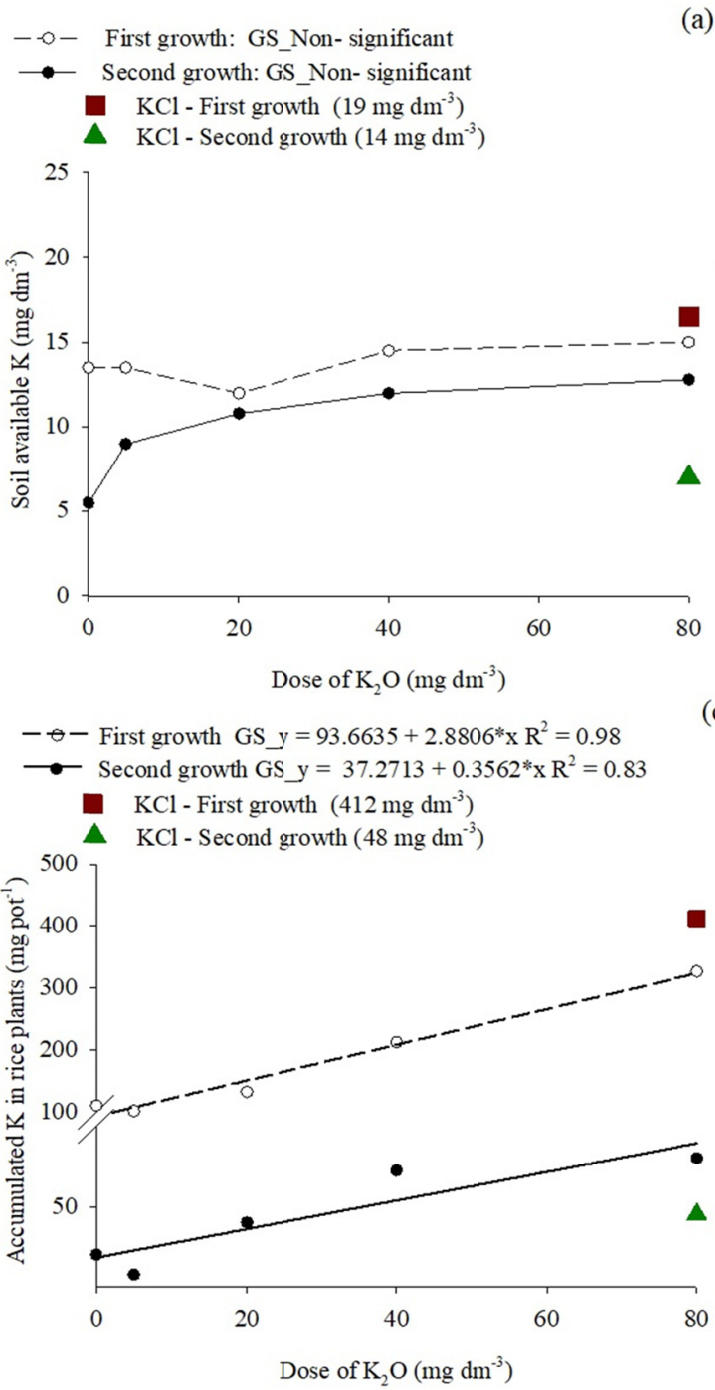

(a)

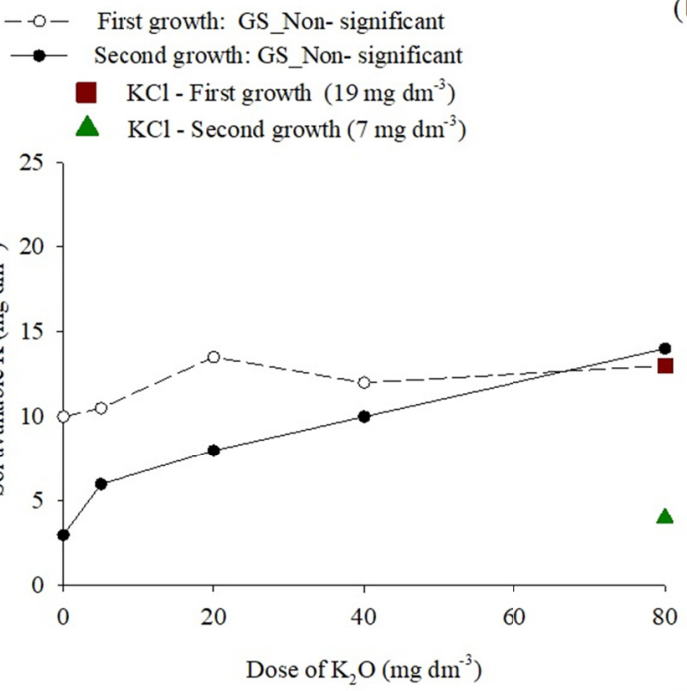

(c)

$-\bullet-$ First growth GS_y $=61.1434+1.3192 * x R^{2}=0.85$

$\multimap$ Second growth GS $y=11.4870+0.3073 * x R^{2}=0.95$

$\mathrm{KCl}$ - First growth $\left(326 \mathrm{mg} \mathrm{dm}^{-3}\right)$

A $\mathrm{KCl}$ - Second growth $\left(27 \mathrm{mg} \mathrm{dm}^{-3}\right)$

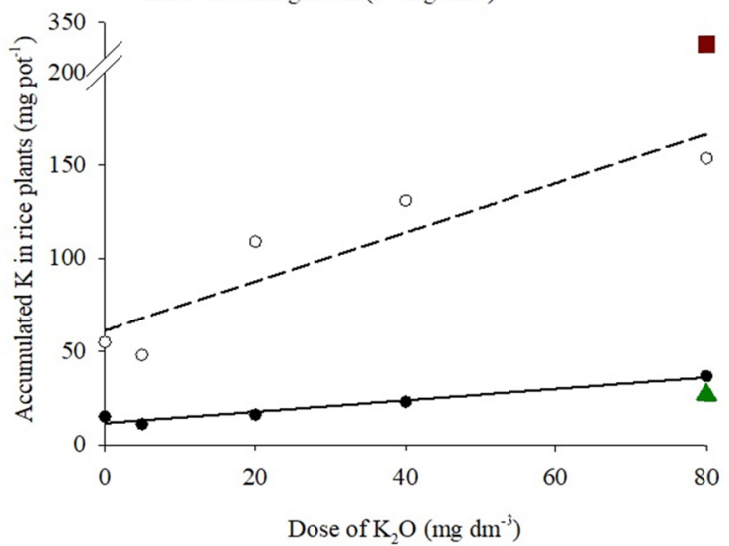

Figure 3. Soil exchangeable K (Resin extraction) contents in clayey (a) and sandy (b) soils and accumulated K in rice plants growth in clayey (c) and sandy (d) with increasing doses of $\mathrm{K}_{2} \mathrm{O}$ through glauconitic siltstone after two consecutive rice growths. Square and triangles symbols refer to the $\mathrm{KCl}$ treatment at dose of $80 \mathrm{mg} \mathrm{dm}^{-3}$ of $\mathrm{K}_{2} \mathrm{O}$ after the first and second rice growth, respectively

After the second rice growth, the application of $20 \mathrm{mg} \mathrm{dm}^{-3}$ of $\mathrm{GS}$, in both clayey and sandy soils, resulted in higher soil available $\mathrm{K}$ contents and accumulated $\mathrm{K}$ in rice plants than $\mathrm{KCl}$ treatments $\left(80 \mathrm{mg} \mathrm{dm}^{-3}\right)$, even when applying GS at a dose four times lower than the standard source (Figure 3). For each $10 \mathrm{mg} \mathrm{dm}^{-3} \mathrm{~K}_{2} \mathrm{O}$ applied through GS in clayey soil, there was a linear increase of $28.8 \mathrm{mg} \mathrm{pot}^{-1}$ and $3.6 \mathrm{mg} \mathrm{pot}^{-1}$ of accumulated $\mathrm{K}$ in rice plants, after the first and second growths, respectively (Figure 3c). Considering the accumulated $\mathrm{K}$ in rice plants growth in sandy soils, increases of $13.2 \mathrm{mg} \mathrm{pot}^{-1}$ were observed after the first growth and $3.1 \mathrm{mg} \mathrm{pot}^{-1}$ after the second growth (Figure 3d). The use of gradual-release $\mathrm{K}$ fertilizers, such as GS, is an alternative to maintain the $\mathrm{K}$ status in soils for sustaining crop production (Jaiswal et al., 2016). Thus, GS may contribute to soil fertility improvement in the medium to long-term, according to their solubility and reactivity with soil. In addition, the use of national nutrient sources has great importance in Brazilian agriculture, reducing its dependence on external fertilizer and providing a source with lower chlorine contents and risk of leaching.

In general, the application of GS also resulted in increases in the content of $\mathrm{Si}$ in the soil and accumulation of Si in rice plants, when compared to control treatment, but was not comparable with the results obtained with the wollastonite (Figure 4). Buck et al. (2011) affirm that the wollastonite is normally used as a positive check because it is a reference source used by many Si researchers. Thus, this standard source presents a relatively high degree of purity and is rich in calcium silicate $\left(\mathrm{CaSiO}_{3}\right)$ (Buck et al., 2011), and its application results in higher 
soil and plant Si contents (Tubana et al., 2016). Despite the fact that wollastonite, calcium silicate, is more soluble and contains higher amounts of $\mathrm{Si}$ than other $\mathrm{Si}$ sources, the refining process of this mineral is labor-intensive and expensive, which limits its mass production as a fertilizer (Tubana et al., 2016).

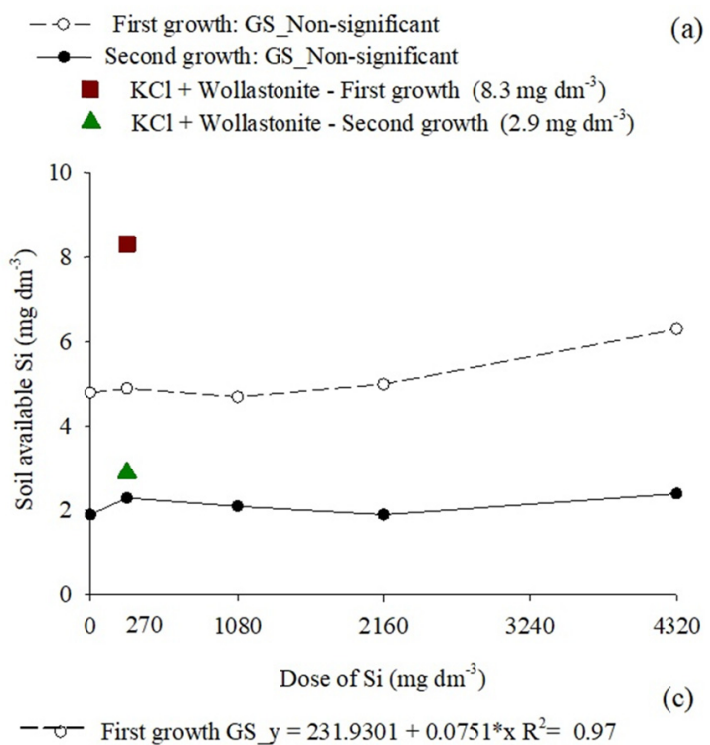
(a) - - - First growth: GS Non-significant
$\rightarrow$ Second growth: GS_Non-significant
- $\mathrm{KCl}+$ Wollastonite - First growth $\left(4.1 \mathrm{mg} \mathrm{dm}^{-3}\right)$
A $\mathrm{KCl}+$ Wollastonite $-\mathrm{Sec}$ ond growth $\left(3.5 \mathrm{mg} \mathrm{dm}^{-3}\right)$

(b)

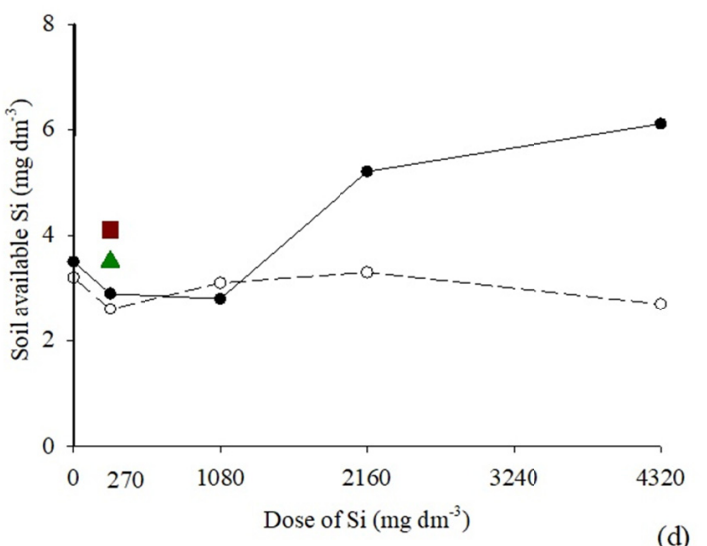

c)

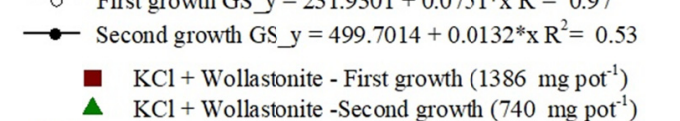

$-\rightarrow-$ First growth GS_y $=270.9030+0.1309 * x-0.000026 * x^{2} R^{2}=0.82$

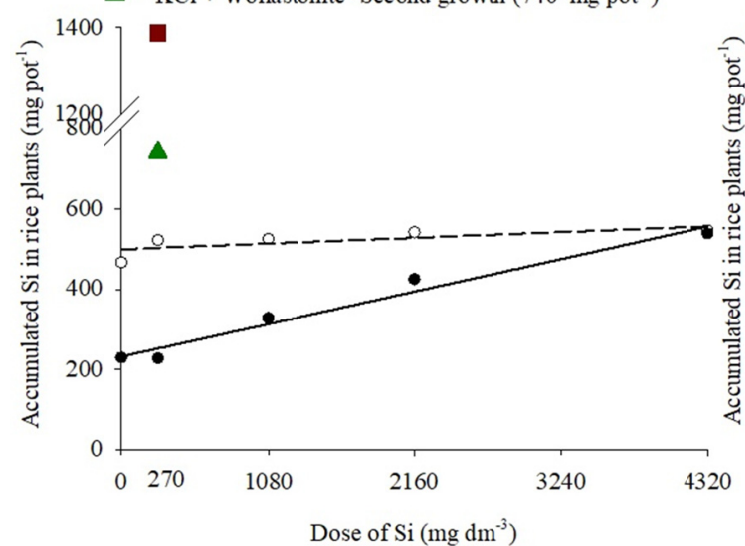

$\longrightarrow$ Second growth GS_y $=95.9703+0.0276^{*} \times R^{2}=0.60$

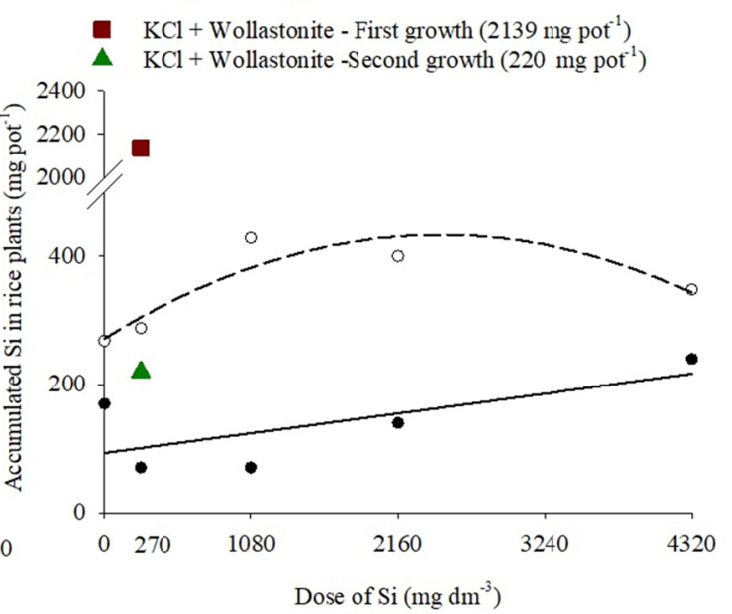

Figure 4. Soil available $\mathrm{Si}$ contents $\left(\mathrm{CaCl}_{2}\right.$ extraction) in clayey (a) and sandy (b) soils and accumulated $\mathrm{Si}$ in rice plants growth in clayey (c) and sandy (d) soils with increasing doses of $\mathrm{K}_{2} \mathrm{O}$ through glauconitic siltstone after two consecutive rice growths. Square and triangle symbols refer to the $\mathrm{KCl}+$ Wollastonite treatment at doses of $80 \mathrm{mg} \mathrm{dm}^{-3} \mathrm{~K}_{2} \mathrm{O}$ and $270 \mathrm{mg} \mathrm{dm}^{-3} \mathrm{Si}$ after the first and second rice growth, respectively

The accumulated Si in rice plants growth in clayey soil increased linearly. Every $10 \mathrm{mg} \mathrm{dm}^{-3} \mathrm{Si}$ through GS increased the Si content by 0.8 , and $0.1 \mathrm{mg} \mathrm{pot}^{-1}$ after the first and second growth, respectively (Figure $4 \mathrm{a}$ and 4b). The Si accumulated after the first growth of rice plants in sandy soil was adjusted to a quadratic equation, with the maximum value at a dose of $2,520 \mathrm{mg} \mathrm{dm}^{-3}$ of Si (Figure 4c). For the second growth in sandy soil, increases of $0.3 \mathrm{mg} \mathrm{pot}^{-1} \mathrm{Si}$ were obtained for each $10 \mathrm{mg} \mathrm{dm}^{-3} \mathrm{Si}$ applied through GS (Figure 4d).

GS can increase soil and rice Si contents. Improvement in the Si contents is mainly relevant in tropical soils, which are typically depleted of Si due to weathering and intensive cropping. In addition, the use of natural Si sources (as the GS), may be a good alternative in soils cultivated with Si-accumulating crops (e.g., grasses), as some crops, such as rice, are capable of removing expressive soil Si concentrations (Meena et al., 2014). Silicon plays a special role in plant health and ecology, mitigating numerous abiotic and biotic stresses, including water and salinity stress, metal toxicities, nutrient imbalance, fungal and bacterial pathogens and insect herbivores (Keeping, 2017). 
Although increases Si content in soil were obtained in both soil types, higher accumulated Si in rice plants were observed in clayey soil (Figure 4a). This fact may be related to positive correlation between soil-available Si content and clay minerals content. Clay minerals with large specific surface have a high capacity to adsorb silicates (Liang et al., 2015).

GS was also efficient in increasing soil and accumulated Mn contents in rice plants (Figure 5).
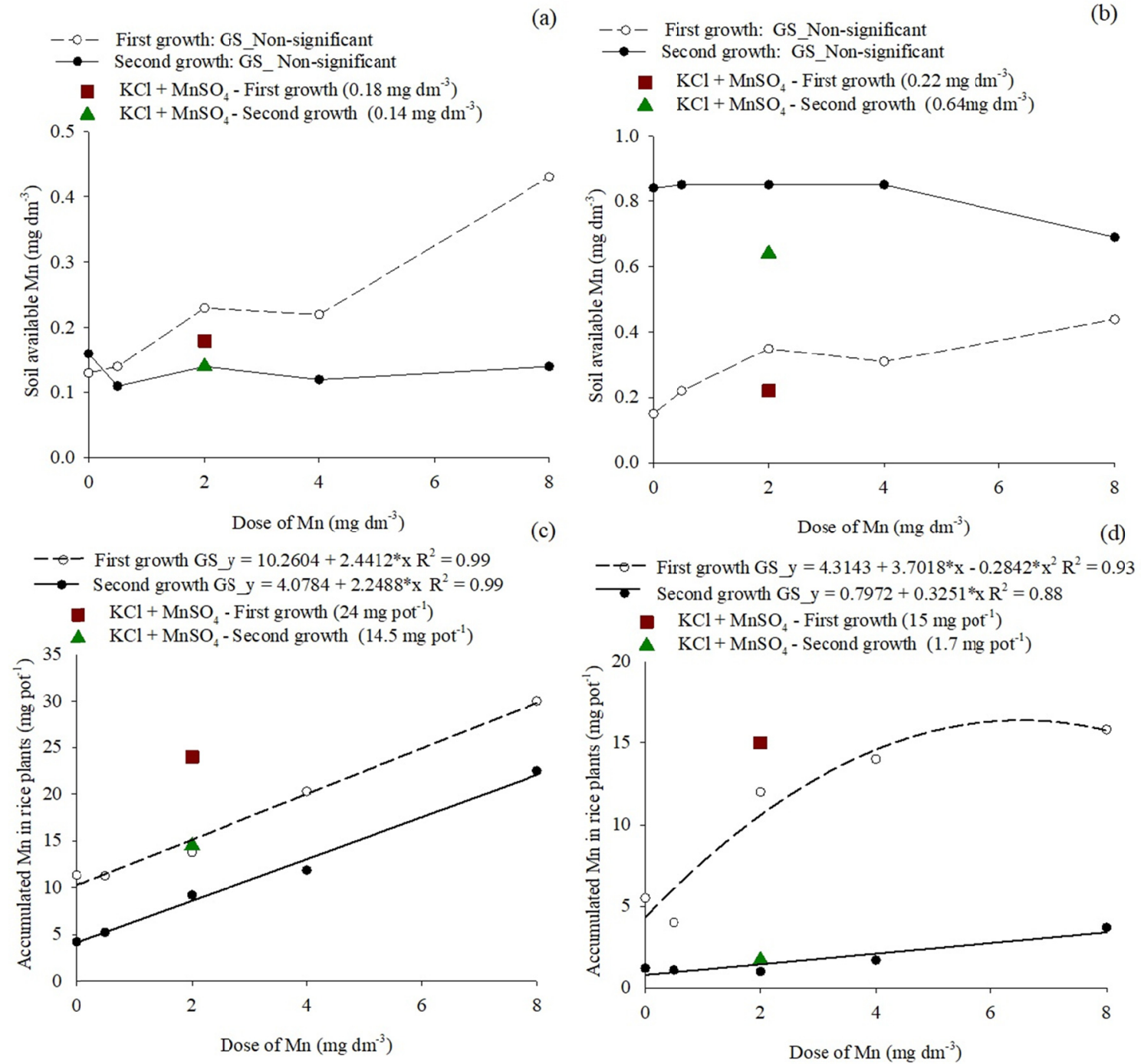

Figure 5. Soil available Mn in clayey (a) and sandy (b) soils and accumulated Si in rice plants growth in clayey

(c) and sandy (d) soils with increasing doses of $\mathrm{K}_{2} \mathrm{O}$ through glauconitic siltstone after two consecutive rice growths. Square and triangle symbols refer to the $\mathrm{KCl}+\mathrm{MnSO}_{4}$ treatment at doses of $80 \mathrm{mg} \mathrm{dm}^{-3} \mathrm{~K}_{2} \mathrm{O}$ and $2 \mathrm{mg}$ $\mathrm{dm}^{-3} \mathrm{Mn}$ after the first and second rice growth, respectively.

After the first rice growth, soil Mn contents ranged from 0.13 to $0.43 \mathrm{mg} \mathrm{dm}^{-3}$ and from 0.15 to $0.44 \mathrm{mg} \mathrm{dm}^{-3}$, following the highest GS dose in clayey and sandy soil, respectively (Figures 5a and 5b). In the second growth, soil Mn contents decreased when compared to control treatment, whereas the element content in plant tissues increased. Linear increases were observed as the applied dose of GS to the clayey soil increased; for every 1.0 $\mathrm{mg} \mathrm{dm}{ }^{-3} \mathrm{Mn}$ applied, there were increases in the accumulated Mn of 2.4 and $2.2 \mathrm{mg} \mathrm{pot}^{-1}$ after the first and second growth, respectively (Figure 5c). For plants growth in sandy soil, linear increases of $0.3 \mathrm{mg} \mathrm{pot}^{-1} \mathrm{Mn}$ were observed after the second growth, while the best results after the first growth are obtained when GS is applied at a dose of $6.5 \mathrm{mg} \mathrm{dm}^{-3} \mathrm{Mn}$. Rice plant is known as a Mn tolerant plant species (Horiguchi, 1988), which accumulate from 5 to 10 times more Mn than other grasses (Foy et al., 1978). The presence of Mn in GS can also improve fertility of weathered tropical soils, which present very low Mn contents. 
In addition to GS application, flooded conditions also directly influenced the Mn availability to rice plants. Under flooded conditions, soils show low redox potential, thus Mn deficiency has decreased in lowland (Tanaka \& Navasero, 1966). As $\mathrm{Mn}$ is an essential element for plants and its deficiency decreased growth and yield, as well as making plants more susceptible to pathogens (Socha \& Guerinot, 2014), the use of GS associated to flooded rice cultivation may be a good alternative to increase Mn availability for plant uptake.

In general, GS efficiency to supply $\mathrm{K}, \mathrm{Si}$ and $\mathrm{Mn}$ to rice plants shows an innovative and sustainable use of nutrient-rich rock to improve tropical soil fertility and rice yields, especially after consecutive crop cycles.

\section{Conclusions}

(1) Results described in this study provide an important understanding of the use of glauconitic siltstone not only as a $\mathrm{K}$ fertilizer, but as source of silicon $(\mathrm{Si})$ and manganese $(\mathrm{Mn})$ in tropical soils, being an efficient alternative to improve tropical soil fertility and increase rice yields.

(2) The application of glauconitic siltstone in tropical soils promoted increases in plant and grain dry matter of flooded rice, as well as $\mathrm{K}, \mathrm{Si}$, and $\mathrm{Mn}$ contents in soil samples and accumulated in plants.

(3) Greater effects following the application of glauconitic siltstone are obtained after the second rice growth due to its gradual release.

\section{Acknowledgements}

The authors are grateful to the Brazilian National Council for Scientific and Technological Development (CNPq), the Coordination of Improvement of Higher Level Personnel (CAPES) and the Foundation of Support Research of the State of Minas Gerais (FAPEMIG) for financial support and scholarships.

\section{References}

Buck, G. B., Korndörfer, G. H., \& Datnoff, L. E. (2011). Extractors for estimating plant available silicon from potential silicon fertilizer sources. Journal of Plant Nutrition, 34, 274-282. https://doi.org/10.1080/ 01904167.2011.533327

Dolcater, D. L., Lotse, E. G., Syers, J. K., \& Jackson, M. L. (1968). Cation exchange selectivity of some clay sized minerals and soil materials. Soil Science Society of America Journal, 32, 795-798. https://doi.org/ 10.2136/sssaj1968.03615995003200060026x

EMBRAPA (Empresa Brasileira De Pesquisa Agropecuária). (2007). BRS Atalanta: Alternativa para o uso racional da água nas lavouras de arroz irrigado do RS. Circular Técnica, Pelotas, RS.

Ernani, P. R., Almeida, J. A., \& Santos, F. C. (2007). Potássio. In R. F. Novais, V. H. Alvarez, N. F. Barros, R. L. F. Fontes, R. B. Cantarutti, \& J. C. L. Neves (Eds.), Fertilidade do solo (pp. 573-780), Sociedade Brasileira de Ciência do Solo, Viçosa, MG.

Fageria, N. K., Carvalho, A. B., Santos, E. P. B., \& Ferreira, Knupp, A. M. (2011). Chemistry of lowland rice soils and nutrient availability. Communications in Soil Science and Plant Analysis, 42, 1913-1933. https://doi.org/10.1080/00103624.2011.591467

Fageria, N. K., Santos, A. B., \& Moraes, M. F. (2010). Yield, potassium uptake, and use efficiency in upland rice genotypes. Communications in Soil Science and Plant Analysis, 41, 2676-2684. https://doi.org/10.1080/ 00103624.2010 .517882

FAO (Food and Agriculture Organization of United Nations). (2015). World Reference Base (WRB) for Soil Resources 2014: International Soil Classification System for Naming Soils and Creating Legends for Soil Maps. FAO, Rome, Italy. Retrieved from http://www.fao.org/3/i3794en/I3794en.pdf

Foy, C., Scott, B., \& Fisher, J. (1998). Genetic Differences in Plant Tolerance to Manganese Toxicity. In R. D. Graham, R. J. Hannam, \& N. J. Uren (Eds.), Manganese in Soil and Plants (pp. 293-307). Kluwer Academic Publishers, Dordrecht, The Netherlands. https://doi.org/10.1007/978-94-009-2817-6_20

Geilfus, C. M. (2018). Chloride: From Nutrient to Toxicant. Plant and Cell Physiology, 59(5), 877-886. https://doi.org/10.1093/pcp/pcy071

Horiguchi, T. (1998). Mechanism of manganese toxicity and tolerance of plants. IV. Effects of silicon on alleviation of manganese toxicity of rice plants. Soil Science and Plant Nutrition, 34, 65-73. https://doi.org/ $10.1080 / 00380768.1988 .10415580$

IBRAM (Brazilian Mining Association). (2012). Information and Analyses on the Brazilian Mineral Economy (7th ed.). Retrieved from http://www.ibram.org.br/sites/1400/1457/00000376.pdf 
Jaiswal, D. K., Verma, J. P., Prakash, S., Meena, V. S., \& Meena, R. S. (2016). Potassium as an important plant nutrient in sustainable agriculture: a state of the art. In V. S. Meena, B. R. Maurya, J. P. Verma, \& R. S. Meena (Eds.), Potassium solubilizing microorganisms for sustainable agriculture (pp. 21-29). Springer, India. https://doi.org/10.1007/978-81-322-2776-2_2

Karimi, E., Abdolzadeh, A., Sadeghipour, H. R., \& Aminei, A. (2012). The potential of glauconitic sandstone as a potassium fertilizer for olive plants. Archives of Agronomy and Soil Science, 58, 983-993. https://doi.org/ $10.1080 / 03650340.2011 .557369$

Keeping, M. G. (2017). Uptake of silicon by sugarcane from applied sources may not reflect plant-available soil silicon and total silicon content of sources. Frontiers in Plant Science, 8, 760. https://doi.org/10.3389/ fpls.2017.00760

Korndörfer, G. H., Pereira, H. S., \& Nolla, A. (2004). Análise de silício: Solo, planta e fertilizante. Boletim Técnico, 2, 34. Retrieved June 20, 2020, from http://www.nutricaodeplantas.agr.br/site/downloads/bt2 gpsi.pdf

Liang, Y., Nikolic, M., Belanger, R., Haijun, G., \& Song, A. (2015). Silicon in Agriculture: From Theory to Practice. Dordrecht: Springer. https://doi.org/10.1007/978-94-017-9978-2

MAPA (Ministério da Agricultura, Pecuária e Abastecimento). (2017). Manual de métodos analíticos oficiais para fertilizantes minerais, orgânicos, organominerais e corretivos (p. 141). Brasília, MAPA/DAS/CGAL. Retrieved from http://www.agricultura.gov.br/assuntos/laboratorios/arquivos-publicacoes-laboratorio/manu al-_in-5_-analiticos-oficiais-para-fertilizantes-e-corretivos_com_capa_final_03.pdf

Meena, V. D., Dotaniya, M. L., Coumar, V., Rajendiran, S., Kundu, S., \& Rao, A. S. (2014). A case for silicon fertilization to improve crop yields in tropical soils. Proceedings of the National Academy of Sciences, 84(3), 505-518. https://doi.org/10.1007/s40011-013-0270-y

Mendes, W. da C., Alves Júnior, J., Cunha, P. C. R. da, Silva, A. R. da, Evangelista, A. W. P., \& Casaroli, D. (2016). Potassium leaching in different soils as a function of irrigation depths. Revista Brasileira de Engenharia Agrícola e Ambiental, 20, 972-977. https://doi.org/10.1590/1807-1929/agriambi.v20n11 p972-977

Moreira, D. S., Uhlein, A., Fernandes, M. L. S., Mizusaki, A. M,. Galéry, R., \& Delbem, D. (2016). Estratigrafia, petrografia e mineralização de potássio em siltitos verdes do Grupo Bambuí na região de São Gotardo, Minas Gerais. Geociências, 35(2), 157-171.

Nader, B., \& Ackroyd, B. (2017). Pre-Feasibility Technical Report-Cerrado Verde Project (NI 43-101). Minas Gerais, Brazil; Verde AgriTech PLC. London.

Prakash S., \& Verma J. P. (2016). Global Perspective of Potash for Fertilizer Production. In V. Meena, B. Maurya, J. Verma, \& R. Meena (Eds.), Potassium Solubilizing Microorganisms for Sustainable Agriculture. Springer, New Delhi. https://doi.org/10.1007/978-81-322-2776-2_23

Ribeiro, L. S., Santos, A. R., Souza. L. F. S., \& Souza, J. S. (2016). Rochas silicáticas portadoras de potássio como fontes do nutriente para as plantas solo. Revista Brasileira de Ciência do Solo, 34, 891-897. https://doi.org/10.1590/S0100-0683201000030003

Santos, H. G., Jacomine, P. K. T., Anjos, L. H. C., Oliveira, V. A., Lumbreras, J. F., Coelho, M. R., ... Oliveira, J. B. (2013). Sistema brasileiro de classificação de solos (Brazilian system of soil classification) (3rd ed.). Embrapa, Rio de Janeiro, RJ.

Socha, A. L., \& Guerinot, M. L. (2014). Mn-euvering manganese: The role of transporter gene family members in manganese uptake and mobilization in plants. Frontiers in Plant Science, 5, 106. https://doi.org/ 10.3389/fpls.2014.00106

Systat Software. (2008). SigmaPlot statistics users guide (11st ed.). Systat Software, Inc., San Jose, CA.

Tanaka, A., \& Navasero, S. A. (1996). Manganese content of the rice plant under water culture conditions. Soil Science and Plant Nutrition, 12, 67-72. https://doi.org/10.1080/00380768.1966.10431185

Teixeira, P. C., Donagemma, G. K., Fontana, A., \& Teixeira, W. G. (2017). Manual de métodos de análise de solo (3th ed.). Embrapa, Brasília, DF.

Tubana, B. S., Babu, T., \& Datnoff, L. E. (2016). A review of silicon in soils and plants and its role in US agriculture: History and future perspectives. Soil Science, 181, 393-411. https://doi.org/10.1097/SS.000000 0000000179 
USDA (The United States Department of Agriculture). (1999). Soil Taxononmy: A basic system of soil classification for making and interpreting soil survey (2nd ed.). USDA, Washington, DC.

Violatti, I. C. A., Gualberto, C. A. C., Silveira, L. H., Santos, G. A., Ferreira, B. C., Machado, P. M. M., \& Pereira, H. S. (2019). Glauconitic siltstone as multi-nutrient fertilizer for Urochloa brizantha cv. Marandú. Australian Journal of Crop Science, 13(8), 1280-1287. https://doi.org/10.21475/ajcs.19.13.08.p1609

Watanabe, K., Tominaga, J., Yabuta, S., Takaragawa, H., Suwa, R., Ueno, M., \& Kawamitsu, Y. (2017). Effects of Different Kinds of Potassium and Chloride Salts on Sugarcane Quality and Photosynthesis. Sugar Tech, 19, 378-385. https://doi.org/10.1007/s12355-016-0486-2

Zorb, C., Senbayram, M., \& Peiter, E. (2014). Potassium in agriculture-status and perspectives. Journal of Plant Physiology, 171, 656-669. https://doi.org/10.1016/j.jplph.2013.08.008

\section{Copyrights}

Copyright for this article is retained by the author(s), with first publication rights granted to the journal.

This is an open-access article distributed under the terms and conditions of the Creative Commons Attribution license (http://creativecommons.org/licenses/by/4.0/). 